Published in:

International Journal of Lifelong Education, vol.28, no.1, 2009, pp. 57-69

\title{
Education, death and awakening:
}

\section{Hesse, Freire and the process of transformation}

\author{
PETER ROBERTS \\ University of Canterbury, New Zealand \\ peter.roberts@canterbury.ac.nz
}

Of all the great novelists of the twentieth century, the German writer Hermann Hesse is arguably one of the most important for educationists. Education is a key theme in a number of Hesse's novels and short stories. Beneath the Wheel (Hesse, 1968a) and Demian (Hesse, 1999) focus on school experiences, while Narcissus and Goldmund (Hesse, 1968b) is in part concerned with learning and teaching in a cloister school during the Middle Ages. More broadly, Hesse's published work is united by a lifelong concern with processes of inner growth. Hesse is one of the finest exponents of the German tradition of the Bildungsroman: the novel of education as formation or development (Swales, 1978; Peters, 1996). Siddhartha (Hesse, 2000a), with its systematic account of the spiritual journey of its central character, provides a good example of Hesse's contribution to this genre, as does the early novel Peter Camenzind (Hesse, 1969). Perhaps the most significant educational work in Hesse’s 
corpus, however, is his last and longest novel, The Glass Bead Game (Hesse, 2000b).

First published (as Das Glasperlenspiel) in 1943, The Glass Bead Game marked the end of a long and difficult process of composition. Hesse worked on the book for more than a decade (Field, 1968; Mileck, 1970). Three years after the initial publication of the book Hesse was awarded the Nobel Prize for Literature. The first English translation of the novel was released under the title Magister Ludi in 1949. The second and more widely cited English version, translated by Richard and Clara Winston, was published in 1969. The main part of the novel focuses on the life of Joseph Knecht, who grows up in Castalia, a 'pedagogical province' of the $23^{\text {rd }}$ century. The highest cultural achievement of Castalia is the Glass Bead Game. The Game remains somewhat mysterious, but readers learn that it blends aesthetic, intellectual and meditative elements, and allows participants to play with the total contents of culture. It is a means for linking all disciplines; a kind of universal language. Knecht rises through the elite schooling system, becomes a member of the Order of the Glass Bead Game, and is eventually appointed to the exalted position of Magister Ludi (Master of the Game). Along the way, however, he questions aspects of Castalian life, his doubts ultimately leading to his unprecedented decision to resign his post as Magister Ludi in favour of a quiet life as a private tutor. The main story of Knecht's life is preceded by the narrator's brief history of the Game and followed by a set of poems and three fictional autobiographies or 'Lives' (presented as posthumous writings from Joseph’s student days).

This paper considers The Glass Bead Game from an educational point of view. I argue that in the life of Joseph Knecht a profound process of educational 
transformation becomes evident. Knecht himself conceives of this as a form of 'awakening'. The paper analyses Knecht's transformation in the light of Paulo Freire's theory of education. Knecht develops a critical consciousness, becoming, over time, less certain of his certainties, more aware of his own incompleteness, and increasingly convinced of the importance of teaching. Dialogue plays a key role in the development of Knecht's critique of Castalia and his understanding of himself and his vocation as a human being. The paper falls into four main parts. The first section details key moments and figures in Knecht's educational life. This is followed by a closer analysis of the dialogical bond that develops between Knecht and two other characters, Plinio Designori and Father Jacobus. The third section discusses the relationship between conscientisation and contemplation for Knecht and others in Castalia. The final part reflects on the significance of death as a theme in the novel and considers some of the educational implications arising from this.

\section{Knecht's educational life}

Little is known about Joseph's early family background. The narrator speculates that his parents may have died or that he may have been removed from unfavourable home circumstances, but says little more than this. For whatever reason, Joseph becomes a child of Castalia. He grows up in the pedagogical province, knowing nothing other than this until adulthood. Few other characters from his childhood years appear, but one important figure is introduced: the Music Master, who becomes a mentor to Joseph and remains an influence throughout his life. From the Music Master, Joseph learns the importance of patience, humility and dedication. He acquires a deep love of music and this remains with him as he grows older. His intellectual talents become 
evident from an early age, and he is sent to Eschholz, an elite school for the brightest students. Joseph has already begun to sense some of the differences between himself and his fellow students. He has moved well ahead of many of them in his studies, and while appreciative of the admiration shown by some, he also becomes aware of a certain distrust among others. From his youth he becomes conscious of his power over others, of his ability to see further and to think at a higher level.

After completing his Eschholz studies, Joseph takes a brief vacation, and then begins the next phase of his schooling at Waldzell. The town of Waldzell is the home of the Glass Bead Game. It is where the Game archives are housed, where the public Game ceremonies are held, and where the Magister Ludi resides. The school at Waldzell accepts only the most talented of the elite students and is devoted to the pursuit of scholarship and the arts. The Glass Bead Game is not taught as a compulsory or official subject in the school at Waldzell, but most of the students devote many hours of private study to it. Many harbour a longing to enter the Order of the Glass Bead Game upon completion of their Waldzell studies, but few are successful in reaching this goal. It is at Waldzell that Joseph meets Plinio Designori, a student from a wealthy family outside Castalia who spends a period of his schooling in the pedagogical province. Joseph and Plinio enter into a series of lively debates. Plinio attacks the protected, restrictive nature of Castalian society while Joseph defends the Castalian way of life. At the same time, Knecht has questions that demand answers, and through his dialogical exchanges with Plinio important seeds of doubt about the superiority of the Castalian system are planted.

At the conclusion of his schooling at Waldzell Knecht enters a period of free study, 
probing the mysteries of the Glass Bead Game more deeply than his fellow students and most of the Masters. He emerges from this period with a renewed appreciation of the beauty of the Game, but also with a willingness to place Castalian society under a critical microscope. The searching questions raised in Knecht's debates with Plinio are investigated further in the two years Joseph spends at a Benedictine monastery in Mariafels. The monastery is one of the oldest centres of learning in the country and a number of its members have an interest in the Glass Bead Game. Joseph is sent to provide introductory courses in the Game. At Mariafels, Joseph forms a strong intellectual friendship with Father Jacobus, a senior figure in the Catholic Church. From his dialogues with Father Jacobus, Knecht begins to comprehend the importance of history. He comes to realise that Castalia was formed through the actions of real human beings and that in time it could disappear. Knecht's time at Mariafels proves beneficial not just in allowing the Benedictines to learn more about the Glass Bead Game but in strengthening ties between the two Orders.

With Joseph’s return to Castalia and his eventual elevation to the supreme position of Magister Ludi, his development takes a further turn. He must acquire adroit administrative and leadership skills, advance the Glass Bead Game to new heights, and manage the burdens of a demanding workload. He comes to appreciate, in a more balanced way and with renewed vigour and depth of understanding, the beauty and value of the Game. He becomes a beacon for all that he sees as worthwhile in Castalia, serving with a maturity beyond his years in the role of Magister Ludi. And yet, at one of his moments of greatest triumph, having led a bold, creative and successful annual Glass Bead Game ceremony, he announces to his friend Fritz Tegularius that one day all of this beauty must pass (Hesse, 2000b, pp. 248-249). 
Knecht becomes acutely aware, while in the midst of a moment of intense celebration, that the Game and the world of Castalia are, in their present state, fragile and unable to be sustained.

As Knecht continues in the role of Magister Ludi, this thought grows into a rigorous but patient and calm questioning of the very foundations of Castalian life. Eventually, the uncertainties that had been present throughout Knecht's adult life lead him to the view that Castalia, with its rigidity and its failure to reach out to others and to learn from them, is doomed. He comes to see that his contribution from this point on lies in teaching. He resigns his position as Magister Ludi and leaves Castalia and the Order of the Glass Bead Game to take on the humble task of tutoring Plinio's son, Tito. Knecht faces the future with some uncertainties but also with vigour and enthusiasm. His new life barely begins, however, when tragedy strikes: he drowns while swimming with Tito in an icy mountain lake. Tito is left, stunned and exhausted, to reflect on what the older man had become to him, and on this unexpected note the main part of the novel ends.

\section{Dialogue, questioning and transformation}

How we are to understand Knecht's educational transformation? The pedagogical theory of Paulo Freire provides a helpful starting point. At the heart of Freire's work is the ideal of humanisation (Freire, 1972a). Humanisation, for Freire, means becoming more fully human through critical, dialogical praxis. From a Freirean point of view, this is a necessarily incomplete process: we can only become more fully human, never fully human. Freire sees humans as unfinished beings, always in a 
process of becoming. Freire identified oppression as a pivotal theme in the twentieth century and saw liberation as a fundamental task for all human beings. Liberation, his work suggests, is not an endpoint to be reached by individuals but a multilayered, social process of struggle (Freire, 1996, 1998a). While education on its own cannot transform oppressive structures, policies and practices, it can play an important role in this process. Liberating education concentrates on the posing of problems rather than the giving of answers; it draws upon, but does not rest with, students' experience and existing knowledge; and it fosters the development of a critical consciousness. In his earlier work (Freire, 1972a, 1972b, 1976), Freire used the term 'conscientisation’ to describe the process of deepening one's understanding of self and society through education. Conscientisation allows students - and teachers - to place personal difficulties in their larger social, cultural and historical contexts. Freire identified a number of intellectual virtues in those seeking to know and transform the world: curiosity, openness, humility, an inquiring and investigative spirit, a willingness to ask questions, the ability to listen, and a commitment to dialogue (Freire, 1985, 1998b; Freire and Faundez, 1989). Knowing, for Freire, is a process one participates in with one's whole being - with reason, emotion and action (Freire, 1997). Freire argued against both authoritarian (banking) and 'anything goes' approaches to education. Freirean dialogue is purposeful and rigorous, with a strong sense of structure and direction (Freire and Shor, 1987). Freire insisted that he was a teacher and not merely a facilitator. He stressed the significance of the responsibilities carried by the teacher and the need for sound preparation and a deep understanding of both the subject matter and pedagogy. Learning, Freire believed, was very much a lifelong process. As necessarily incomplete beings we always have more educational work to do. Education allows us to live with - indeed, embrace - uncertainty. Education 
encourages us to accept a certain kind of restlessness; there will always be more searching to do, further problems to address and questions to ask, fresh dialogues to enter into, and new actions that must be taken to change the world.

Knecht's development is consistent with many features of Freire's educational ideal. Knecht has an inquiring and investigative disposition; he loves the Glass Bead Game and respects the traditions and rituals associated with it. But he is not prepared to simply accept what others have to say about the Game and the supremacy of the Castalian way of life. He seeks to truly know the Game, immersing himself deeply in its inner mysteries. In doing so, however, he does not lose sight of the larger context within which the Game occurs. Dialogue plays a crucial role in the development of Knecht's critical, questioning approach to himself, his purpose in life, and the nature of Castalian society. Knecht, Jacobus and Plinio are all transformed through their dialogical relationships with each other. This transformation does not, however, occur in a uniform or straightforward way. Joseph and Plinio both have much to learn about life when they first meet each other, and the 'point scoring' nature of some of their early exchanges provides both a stimulus and an impediment for their further education and growth as human beings. Their enthusiasm for a dialogical 'battle' is as much an assertion of wills as an attempt to learn, and this inhibits their ability to gain as much as they could from their relationship with each other. Sometimes it seems as if their desire is not merely to know but also to win, and the calm, concentrated attention necessary to more deeply understand an opposing point of view suffers as a result. But as their relationship develops and matures, their ability to realise the fuller potential of educational dialogue increases. Through their debates they sharpen their intellects, hone their abilities in argument, and develop strong 
leadership qualities. They gain considerable respect from their peers, paving the way for their later elevation to positions of importance in their different worlds: Joseph as Magister Ludi within the protected confines of Castalia, Plinio as a senior political figure in the outside world.

Father Jacobus is older than Knecht and can draw on a broader range of life experiences than his Castalian friend. Yet, he has also become, in some respects, more 'set in his ways' than Joseph. He has greater depth in scholarly and practical knowledge than Knecht, but his views of the pedagogical province have been coloured by decades of alienation between the Church and Castalia. Jacobus, for all his experience, is still very much a man of his times, shaped by the prejudices of his institution, with a somewhat caricatured picture of life of Castalia. Without the benefit of his time with Knecht, there is every possibility his unreflective and somewhat ill-informed indictment of Castalia, its inhabitants and the Glass Bead Game would have become even more entrenched. Knecht also learns a great deal from Father Jacobus. As a Castalian, he had been encouraged to view history with suspicion; to regard earlier times and other worlds as inferior to the intellectual and cultural environment created in the pedagogical province. From Father Jacobus, Knecht comes to appreciate how Castalia had been formed, how its privileges had been sustained by others, and why its disdain for history is a potentially fatal weakness. The dialogical relationship between Joseph and Father Jacobus developed over a period of two years - plays a pivotal role in changing not only Knecht and Jacobus themselves but also their respective Orders. Father Jacobus is already a world leader in his Order, and it is clear that the gradual but eventually significant shift in his view of the pedagogical province and its inhabitants will impact 
directly on the future direction of the Church. The impact on Castalia is not just in the improvement of relations with the Church (something Knecht's superiors had had in mind all along in sending him to Mariafels) but, later, on the direction Knecht takes in the position of Magister Ludi.

Joseph Knecht, unlike other senior figures in the Order of the Glass Bead Game, becomes, as Freire (1997) would say, less certain of his certainties as he grows older. In this respect, he stands opposed to the spirit of Castalia. For the pedagogical province is founded, at the time of Knecht's departure, on a kind of excessive certainty: an unreflective smugness about Castalia's triumph over the problems of the past. The narrator, a representative of Castalia, writes disparagingly in his Introduction of what he sees as trivial amusements in the Age of Feuilletonism (the period of bourgeois individualism in the first half of the twentieth century). These include crossword puzzles and popular newspapers. Yet, to outsiders, the subjects addressed by scholars in Castalia can appear to be equally insignificant. Even the Game itself, the ultimate expression of Castalian intellectual and aesthetic life, rests on fragile foundations. As one commentator has put it, the Glass Bead Game is 'a sham, a singularly jejune academic exercise of as much significance as, say, the reconstruction of the conjugations of hypothetical irregular Sanskrit verbs’ (Bandy, 1972, p. 304).

At the end of the main part of the novel, Knecht remains an incomplete being, and is aware of himself as such. This is, in part, what distinguishes him from many of his Castalian colleagues; Knecht has a sense that he has more to offer than the pedagogical province will allow. Castalia, with its closed, hierarchical, inward- 
looking attitudes and structures, cannot provide what Knecht needs for his further educational development. As Knecht has grown older, he has felt an increasingly strong need to teach - to play a role in shaping and guiding young people, not just within but beyond the pedagogical province. This sets him apart from most of his fellow Castalians, who see themselves as separate from and superior to the rest of world. Knecht's Circular Letter to the Board of Educators, in which he outlines his reasons for seeking to leave the Order, is the culmination of the process of transformation he has undergone. In his letter, Knecht shows that he has changed even if Castalia has not. Knecht can no longer live within the limits imposed by Castalian society and breaks away to commit himself to the new task of teaching. Success in the Castalian system no longer matters to Knecht and he longs to taste life outside. The rejection of Castalian authority is simultaneously an assertion of Knecht's authority: an expression of the self-will that Hesse regarded as so important.

At the same time, Castalia continues to live through Knecht even while he is arguing against it. Knecht has changed but he has changed under Castalian circumstances. As such, he is, in many ways, ill prepared for the world outside and for the vocation of teaching Tito. Knecht has not raised a family and he has experienced little of political and economic life outside Castalia. But he is more open minded than many of his Castalian colleagues and is willing to learn. While Knecht's growth as a human being can be seen as a process of transformation, this is not to say that nothing has remained constant over the course of his life. There are elements of his character - his dedication, his concentration, his relative calmness, his ability to apply himself to intellectual tasks, and his reflectiveness - that served him well in the Castalian education system, allowed him to flourish as a Glass Bead Game player, and stood 
him in good stead as Magister Ludi. These qualities also contributed to his decision to leave. These character traits may have been present from the beginning (cf. Cohn, 1950), but the form they take at different moments in his life is influenced by the people, events and challenges he faces along the way.

\section{Conscientisation, contemplation and awakening}

Knecht conceives of his own transformation as a process of 'awakening'. He reflects at different moments in his life on what this process means to him. The concept of awakening Knecht comes to embrace near the end of his life has much in common with the Freirean notion of conscientisation. Awakening, Knecht comes to believe, means deepening one's understanding of oneself, others and the world. This is not a linear, finite process but an ongoing one, with multiple moments of awareness. It demands ethical commitment, the acceptance of responsibility rather than escape from it, and service to others (see Hesse, 2000b, pp. 357-358). In these respects and others, awakening is virtually indistinguishable from conscientisation. There are, however, elements in Knecht's process of awakening that are not addressed, at least not directly or in any detail, in Freire's work. Knecht, like other Castalians, is trained in the art of meditation. The meditation practised by Castalians is closely allied with their intellectual culture. In his Introduction, the narrator notes that contemplation was the final essential component added to the Game:

What had formerly mattered was following the sequences of ideas and the whole intellectual mosaic of a Game with rapid attentiveness, practiced memory, and full understanding. But there now arose the demand for a deeper 
and more spiritual approach. After each symbol conjured up by the director of a Game, each player was required to perform silent, formal meditation on the content, origin, and meaning of this symbol, to call to mind intensively and organically its full purport. The members of the Order and of the Game associations brought the technique and practice of contemplation with them from their elite schools, where the art of contemplation and meditation was nurtured with the greatest care. (Hesse, 2000b, pp. 29-30)

The importance of meditation is reinforced by the Music Master, Joseph's revered early mentor, when Knecht calls upon him during a difficult period. One of Knecht’s first moves after learning he is to become Magister Ludi is to enter a meditation room. Knecht also remembers fondly the contemplative atmosphere of the bamboo grove where he visits Elder Brother, another quiet influence on his life. When Knecht's highly strung friend Tegularius is in an overwrought state and makes an inappropriate outburst to a colleague, Knecht sends his meditation master to him 'to calm the troubled soul' (p. 215). And Master Alexander turns to meditation in the difficult conversations that follow Knecht's request to leave the Order. Meditation, then, is an important part of Castalian life, and it allows Knecht to reflect calmly and carefully on his past, present and future. At different moments in his awakening, Knecht contemplates the path he has taken, the influences on his thinking, and the possibilities that lie ahead of him. Meditation deepens his knowledge and experience of the Glass Bead Game and it helps him in addressing ethical and epistemological questions. Meditation also proves beneficial in dealing with dilemmas arising from human relationships. 
While Freire does not discuss meditation in his work, aspects of his epistemology resonate with the Castalian art of contemplation. Freire describes a process of 'epistemological encircling' that, to some extent, resembles the contemplative nature of some forms of concentrative meditation. For Freire, in contemplating an object of study, it is necessary to first gain a certain distance from it. This does not mean isolating the object but rather seeking to understand it rigorously and holistically - in its context and in relation to other objects, phenomena and processes (cf. Freire, 1997, p. 92, 2004, p. 84). Joseph Knecht can be distinguished from most of his Castalian colleagues in this respect. His meditative activity, at times, includes a form of reflection in which he seeks to understand a problem or situation in its wider context. Joseph, influenced by his time with Father Jacobus, brings a sense of history to the art of contemplation. His meditative reflections on his own history form an important part of his developing critical consciousness as he grows older. For the majority of Castalians, however, meditation is limited in its scope and substance. As Durrani (1982, p. 662) puts it, ‘[w]hat should serve as a means of achieving self-knowledge is all too often abused as an easy way of disposing of crises and unwanted emotions'. Alexander's recourse to meditation as a kind of 'fix' during his strained conversations with Knecht near the end of the main part of the book is perhaps the clearest example of this. Meditation becomes a means for suppressing rather than exploring feelings, a 'substitute for experience' - something to be administered much as 'another man might light a cigarette or pour himself a drink' (p. 663). Meditation of this kind becomes an escape from critical consciousness rather than an integral part of it.

Meditation, for Knecht, works hand in hand with the development of other ethical attributes. Knecht has the courage to question prevailing wisdom in Castalia and the 
commitment to stand behind his convictions. These qualities are evident right up to the moment of Knecht's death. Hesse argued that Knecht's decision to follow Tito into the icy waters of a mountain lake was a moment of profound pedagogical importance (see Mileck, 1978). It is Tito, full of youthful exuberance, who decides to go for an early morning swim, aiming to reach the other side of the lake ahead of the sun's rays. Knecht, despite having felt unwell the previous night, realises he must work hard to win over his young charge. While his instincts warn him to be careful, he also does not wish to disappoint his student by 'opposing cool, adult rationality to this invitation to a test of strength' (Hesse, 2000b, p. 402). He leaps into the lake, the chill of the water gripping him even more fiercely than he had anticipated. He sets out after Tito, but his physical strength is not on a par with his strength of character and will. Tito looks back and, realising he can no longer see Joseph, searches frantically for him. With his own endurance nearing its end, he is forced to return to shore, where he sits, stunned and 'overpowered by perplexity and deep sorrow' (p. 403). For Hesse, Knecht's willingness to follow Tito will educate the younger man 'more than all the sermons of the wise' (cited in Mileck, 1978, p. 304). In this single moment, it might be said, the germ of an entire pedagogical theory can be found. Teaching, Hesse seems to suggest, is a sacrificial process, and education is, ultimately, a preparation for death. These ideas are developed further in the next section.

\section{Education, death and new life}

Death is an important theme in The Glass Bead Game. The novel pays close attention to the circumstances leading up to the probable death of Bertram, the Deputy of the 
Magister Ludi in office prior to Knecht's investiture. The elderly Music Master's last months of life are also examined in some detail. Knecht's death is, however, undoubtedly the most important in the book. The final moment in the main part of the novel can be seen as both an end and a beginning. It provides a crucial bridge between the 'official' account of Knecht's life furnished by the narrator and the rich inner dialogue - with all of its questioning and uncertainties - present and ever evolving in Joseph from early adulthood. This thought process is evident in the imagined 'Lives' Knecht constructs (three of which are presented after the main part of the novel), where death is seen as a fundamental part of the teaching and learning process. While Knecht dies suddenly and tragically, he is, it might be argued, still well prepared for his own death. He has given careful thought in his fictional autobiographies to the meaning of death and its relationship, through education, to life. He is, by the time he leaves the Order, accepting of his own limits and uncertainties. He has, in Freirean terms, a strong sense of his need to continue becoming more fully human. He does not fulfil all that he might have been capable of achieving in his post-Castalian life, but in his brief period of involvement with Tito he leaves a crucial mark on the younger man.

Hesse, it seems to me, wanted to convey a deeper pedagogical point here. If our physical death can be seen as the culmination of a lifelong educational process, devotion to the task of teaching (in any one of its many diverse forms) can be conceived as a kind of preparation for death. Facing the fact that we will die, that our lives as we presently know them will end at a certain point, encourages us (or can encourage us) to confront the question of possibilities and limits in a lifetime. It can prompt us to ask what really matters - in our lives, in the lives of others, and in the 
world around us. In Being and Time, Heidegger (1996) maintains that death is characteristically discussed as a constantly occurring 'case': as something which strikes 'the they'. This '[e]ntangled, everyday being-toward-death', he says, 'is a constant flight from death. Being toward the end has the mode of evading that end reinterpreting it, understanding it inauthentically, and veiling it’ (pp. 234-235). Ernest Becker (1973), too, observed that 'the idea of death, the fear of it, haunts the human animal like nothing else; it is a mainspring of human activity - activity designed largely to avoid the fatality of death, to overcome it by denying in some way that it is the final destiny for man' (p. xvii). An educational process of the kind undergone by Joseph Knecht can allow us to face death head on, with neither exaggerated boldness nor debilitating terror. Reflection on our own mortality can itself be an educative process, leading to a more mature, clearer and well reasoned sense of what we will commit to and why, of how we will prioritise the limited time we have, and of how we might involve ourselves in the lives of others. As Puolimatka and Solasaari (2006) put it:

Reflection on the reality of death and its unavoidability increases one's consciousness of life's limitations. It reveals the unrealistic nature of many expectations and forces people to understand that reality does not conform to their desires and hopes. A truly experienced person understands that she controls neither time nor the future. An experienced person has learned that all plans are uncertain, because reality can be completely different from what one expects. (p.207)

Freire talks about educators undergoing 'Easter experiences', arguing that they must 
'die as elitists so as to be resurrected on the side of the oppressed' (Freire, 1985, pp. 122-123). This, for Freire, means a deep change in the consciousness of teachers; a shift that goes beyond mere commemorative rhetoric to a genuinely transformative, biophiliac (life-loving) process of educational resurrection. It involves, among other things, the renunciation of myths often held dear by teachers and others who work with oppressed groups: a belief in their own superiority, their purity of soul and impartiality, and their role as saviours of the poor. The kind of Easter experience Freire has in mind also entails a rejection of the lust to possess. Freire sees this as symptomatic of a necrophiliac (death-loving) view of the world. 'Why', he says, 'should I be interested in rebirth if I hold in my hands, as objects to be possessed, the torn body and soul of the oppressed? I can only experience rebirth at the side of the oppressed by being born again, with them, in the process of liberation' (p. 123).

Freire's notion of an Easter experience is not without its problems. His earlier accounts of this form of experience employ a language suggestive of a clear-cut, binary division between oppressed and non-oppressed groups, downplaying the multiple, often overlapping and conflicting layers at which oppression can operate. (This was addressed to a considerable extent in later writings: see Mayo, 1999; Roberts, 2000.) Freire also does not pay sufficient attention to the inner complexities of a 'rebirthing' or resurrection experience. He recognises that old ideas, attitudes and beliefs are seldom simply abandoned. The process of transformation to which he refers is, moreover, based not on miraculous revelation or shallow 'quick fix' solutions but on a complex, difficult and often lengthy process of critical reflection, dialogue and social action. Yet, Freire does not fully get to grips with the unconscious aspects of educational transformation and the ways in which deeply 
ingrained habits of thought may continue to exert a 'hidden' influence on our understanding of, and conduct within, the world. The specifically Christian origins of the metaphor of an 'Easter experience' can also be off-putting.

Nonetheless, Freire hints at something important for teachers: the idea that a commitment to teaching necessitates a kind of symbolic death. In Knecht's case the death is, in the end, a literal physical death, but there are other deaths throughout the main part of the novel and the autobiographies that are symbolic in nature. In taking on the responsibilities of Magister Ludi, Knecht must allow the freedom he experienced as a young Castalian student to die. Knecht’s decision to leave the Order requires of him that he give up all he has ever known; he must, in effect, be 'reborn', not only as a private tutor but as a citizen of a new world. The theme of sacrifice also figures prominently in the three fictional autobiographies. For Josephus (in the second autobiography) to teach through the art of patient listening he must sacrifice a part of himself, resisting the urge to speak while also being prepared to allow others draw renewed strength from him. And the price for Dasa (in the third autobiography) to pay in learning the lessons he will need to teach others, as the old yogin has taught him, is the experience - real or imagined - of losing his son. Teachers, it might be argued, have to make multiple sacrifices in fulfilling their duties - giving up not only their time but a part of themselves to others and to the pursuit of knowledge. Conceived in this way, education must, as Freire noted on many occasions, be seen as a profoundly risky process; an unsettling, often uncomfortable, form of experience that leaves a permanent mark on human lives. 


\section{Concluding comments}

The Glass Bead Game is a novel of transformation. The principal focus in considering this from an educational point of view is Knecht himself. Given the narrative structure of The Glass Bead Game, readers must work hard to 'find' Joseph Knecht (Bandy, 1972), but the rewards in seeking him are great. Through Joseph's thoughts, feelings, actions, and relationships with others, a rich, complex picture of educational transformation emerges. This is, in part, what gives novels such as The Glass Bead Game their value. A serious novel can show, in a way that is often not possible in theoretical work, the nature and consequences of transformative processes for individual lives. That said, The Glass Bead Game is not just about the life of Joseph Knecht; the notion of transformation is also addressed in other ways. The transformation from the Feuilleton Age (the first half of the twentieth century) to the Castalian era, as described by the narrator in the General Introduction, is significant in framing much of the subsequent discussion of the Glass Bead Game and other aspects of Castalian life. Details of this process of transformation are, however, rather sketchy. In another sense, the significance of transformation is revealed by what does not occur as much as by what does. Castalia, the book shows, fails to transform itself and is thus doomed to disappear. It is the inwardness of Castalia, its inability to change, that will lead to its inevitable decline. The novel teaches us that societies and the systems of organisation within them need robust means for critically reflecting on their own policies, practices, and ways of being in the world (cf. Wilde, 1999). They need, the book shows, to look outwards as well as self-critically inwards; to foster interaction, dialogue and debate; and to develop forms of teaching and learning that are genuinely supportive of questioning and critique. These ideas may not be new but 
they must, as Freire would have said, be continuously relearned as educators face the distinctive challenges posed by their own time, culture and social circumstances. 


\section{References}

Becker, E. (1973). The denial of death. New York: The Free Press.

Bandy, S.C. (1972). Hermann Hesse's Das Glasperlenspiel: In search of Josef Knecht. Modern Language Quarterly, 33, 299-311.

Cohn, H.D. (1950). The symbolic end of Hermann Hesse’s ‘Glasperlenspiel'. Modern Language Quarterly, 11, 347-357.

Durrani, O. (1982). Hermann Hesse’s Castalia: Republic of scholars or police state? Modern Language Review, 77, 655-669.

Field, G.W. (1968). On the genesis of the Glasperlenspiel. The German Quarterly, $41,673-688$.

Freire, P. (1972a). Pedagogy of the oppressed. Harmondsworth: Penguin.

Freire, P. (1972b). Cultural action for freedom. Harmondsworth: Penguin.

Freire, P. (1976). Education: The practice of freedom. London: Writers and Readers.

Freire, P. (1985). The politics of education. London: MacMillan.

Freire, P. (1996). Letters to Cristina: Reflections on my life and work. London: 
Routledge.

Freire, P. (1997). Pedagogy of the heart. New York: Continuum.

Freire, P. (1998a). Pedagogy of freedom: Ethics, democracy, and civic courage. Lanham, Maryland: Rowman and Littlefield.

Freire, P. (1998b). Teachers as cultural workers: Letters to those who dare teach. Boulder, Colorado: Westview Press.

Freire, P. (2004). Pedagogy of indignation. Boulder and London: Paradigm.

Freire, P. \& Faundez, A. (1989). Learning to question: A pedagogy of liberation. Geneva: World Council of Churches.

Freire, P. \& Shor, I. (1987). A pedagogy for liberation. London: MacMillan.

Heidegger, M. (1996). Being and time (J. Stambaugh, Trans.). Albany: State University of New York Press.

Hesse, H. (1968a). Beneath the wheel (M. Roloff, Trans.). New York: Picador. (Original work published 1906)

Hesse, H. (1968b). Narcissus and Goldmund (U. Molinara, Trans.). New York: Picador. (Original work published 1930) 
Hesse, H. (1969). Peter Camenzind (M. Roloff, Trans.). New York: Picador. (Original work published 1904)

Hesse, H. (1999). Demian (M. Roloff \& M. Lebeck, Trans., T. Mann, Introduction). New York: Perennial Classics. (Original work published 1919)

Hesse, H. (2000a). Siddhartha (S.C. Kohn, Trans., P.W. Morris, Introduction). Boston: Shambhala. (Original work published 1922)

Hesse, H. (2000b). The Glass Bead Game (R. Winston \& C. Winston, Trans.). London: Vintage. (Original work published 1943)

Mayo, P. (1999). Gramsci, Freire and adult education: Possibilities for transformative action. London: Zed Books.

Mileck, J. (1970). Das Glasperlenspiel: Genesis, manuscripts, and history of publication. The German Quarterly, 43, 55-83.

Mileck, J. (1978). Hermann Hesse: Life and art. Berkeley: University of California Press.

Peters, M. (1996). Cybernetics, cyberspace and the university: Herman Hesse's The Glass Bead Game and the dream of a universal language. In Poststructuralism, politics and education (159-176). Westport, CT: Bergin 
and Garvey.

Puolimatka, T. \& Solasaari, U. (2006). Education for death. Educational Philosophy and Theory, 38, 201-213.

Roberts, P. (2000). Education, literacy, and humanization: Exploring the work of Paulo Freire. Westport, CT: Bergin and Garvey.

Swales, M. (1978). The German Bildungsroman from Wieland to Hesse. Princeton, N.J.: Princeton University Press.

Wilde, L. (1999). The radical appeal of Hermann Hesse’s alternative community. Utopian Studies, 10, 86-97. 